\title{
REAL CONVERGENCE IN THE NEW EU MEMBER STATES
}

\author{
Borut Vojinović, Žan Jan Oplotnik*
}

\begin{abstract}
:
This paper presents the analysis of unconditional $\beta$ and $\sigma$ convergence among the ten European countries that accessed the European Union in 2004. Unconditional $\beta$ convergence means that the less developed countries (with lower GDP per capita) grow faster than the more developed countries (with higher GDP per capita). $\sigma$ convergence exists when income differentiation among economies decreases over time. Our results confirm the existence of both types of convergence in the second half of the 1990s and the 2000s. The poorer New EU Member States grew generally faster than the richer New EU Member States. As a result, the income gap among these countries has decreased (although it still remains quite large). The convergence occurred at the rate of $2.87 \%$ in the years $1995-2006$ and $3.23 \%$ in $1996-2006$. This result is very similar to the results of other analyses on the subject.
\end{abstract}

Keywords: economic growth, economic convergence, transitional economies, European Union

JEL Classification: F02, F43, O11, O19

\section{Introduction}

In this paper, we analyse the real economic convergence among ten European countries (EU-10) that accessed the European Union in 2004. Our group includes 8 Central and Eastern European countries (CEE-8): the Czech Republic, Estonia, Hungary, Latvia, Lithuania, Poland, the Slovak Republic, and Slovenia; as well as two island countries from Southern Europe: Cyprus and Malta. We focus on two concepts of real economic convergence: unconditional (absolute) $\beta$ convergence and $\sigma$ convergence.

$\beta$ convergence means that the less developed countries (with lower GDP per capita) tend to grow faster than the more developed countries (with higher GDP per capita). $\sigma$ convergence occurs when income differentiation between economies decreases over time. According to Rey and Montouri (1998), $\beta$ convergence has been more popular with macroeconomists, while $\sigma$ convergence has been used more in regional science and economic geography literature. $\beta$ convergence does not necessarily imply $\sigma$ convergence if each country's income level is persistently subject to random disturbances that affect country-specific growth rates (Barro, Sala-i-Martin, 1990).

* Borut Vojinović, Business School Maribor, Prešernova 1, 2000 Maribor, Slovenia (borut.vojinovic@guest.arnes.si); Žan Jan Oplotnik, Faculty of Economics and Business, EPF Maribor, Razlagova 14, 2000 Maribor, Slovenia (zan.oplotnik@uni-mb.si). 
Our analysis is based on International Monetary Fund data (World Economic Outlook Database, September 2006). The period covered is 1992-2006.

For all eight CEE countries the initial period of transition is characterized by drastic falls in output; high inflation and rising unemployment (Fischer and Sahay, 2000). The most drastic example is the negative real GDP growth of about 40\% in Latvia in 1992. Economic growth in the CEE countries depends on two sets of factors. On the one hand, economic growth depends on factors directly related to the transition process, which can be further separated into initial conditions and reform policies. On the other hand, it depends on the determinants of long-run growth as described by various theoretical models of economic growth (according to the neoclassical theory, these determinants are technical progress and factor accumulation: labour and capital). Consensus in the literature is that initial conditions do have a significant effect at the beginning of transition, but that their importance is declining rapidly (see e.g. deMelo et al., 1997, Havrylyshyn et al., 1998). It is found that countries with adverse initial conditions can nevertheless achieve a positive outcome by strong commitment to - and therefore a large extent of - reforms. DeMelo et al. (1997) find that initial conditions do matter, but that the adverse effect of unfavourable initial conditions can be overcome by strict commitment to reform policy.

The further the country is in its transition process towards a market economy, the more important the standard determinants of economic growth become. Thus, unless a large backlash is observed in these countries, medium-run growth projections may be based on the neoclassical growth framework (with possibly allowing for transitional effects). Hence, if the growth process is described adequately by the neoclassical growth theory, we may assume that the countries have developed in line with convergence hypothesis.

However, the neoclassical growth theory is only one from many arguments behind the existence of convergence. There are many other reasons which allow us to expect that the EU-10 countries reveal strong income-level convergence. These include: trade liberalization (significant tariff cuts and export-promoting policies), capital mobility (huge FDI inflow, especially to CEE-8 countries), labour migration, structural and institutional reforms, policy co-ordination, as well as the EU funds aimed at developing poorer regions and countries. All these factors contributed to equalizing income levels between New EU Member Countries.

By the end of the 1990s, inflation had been brought down to one-digit or low two-digit numbers. Thus, among New Member Countries, stabilization policy has been successful and growth is now widely experienced (Vojnović, 2006). Concerning predictions of economic growth and GDP per capita, it is essential to analyse (based upon the historically observed growth process) growth rates, reached before getting the full membership of the EU of above mentioned economies.

The paper is composed of six points. Point 1 is this introduction. Point 2 presents the theoretical benchmark for our analysis. Point 3 includes the brief review of other empirical studies on the subject. Points 4 and 5 present the results of $\sigma$ convergence and $\beta$ convergence analysis. Point 6 concludes. We analyse beta convergence for the full 1992-2006 period and five sub-periods: 1992-1997, 1995-2006, 1996-2006, 2002-2006, and 2004-2006 for EU-10 countries. We divided the whole period 1992-2006 into the shorter ones in order to test the reliability of the results on convergence. 


\section{Theoretical Background}

Our analysis is based on neoclassical models of economic growth: the Solow model (Solow, 1956; Swan; 1956), the Ramsey model (Ramsey, 1926; Cass, 1965; Koopmans, 1965), the Diamond model (Diamond, 1965), and the Mankiw-Romer-Weil model (Mankiw et al., 1992).

These models confirm the existence of conditional $\beta$ convergence. It means that the less developed economies grow faster than the more developed ones if all the economies concerned tend to reach the same steady-state. If steady-states differ, convergence need not take place.

According to the standard neoclassical growth model of Solow, economic growth is driven by technical progress and the accumulation of two factors of production - labour and capital. Technical progress is assumed to be exogenous, but sustained growth in per capita terms does not occur without it. Both labour and capital are assumed to be paid a return that is equal to their marginal products. Labour is determined by population, which is assumed to be growing at an exogenous rate. Consequently, labour too is exogenous. The capital stock is determined by investment and the investment rate (equal to the saving rate) is typically assumed to be constant and exogenous. Consequently, output, investment and the capital stock will all grow at the same long-run growth rate. Labour and capital have a positive effect on production but their marginal products are diminishing. Convergence occurs because of diminishing and lower returns to investment in more developed and capital-abundant countries and sectors. Capital investment spreads to new, less-capital abundant countries and sectors, where returns to investment are higher or labour migrates to the more developed countries, where wages are higher. Nevertheless, capital accumulation cannot sustain growth in the long term, while growth in total factor productivity can. The Solow model does not predict absolute convergence, but it does predict that per capita income in any given country converges to that country's steady-state value. Yet, if we control the determinants of the steady state, we get 'conditional convergence' (Mankiw et al., 1992).

According to the conditional convergence hypothesis, if countries have access to the same technology and their population growth rates as well as the savings rates are the same, but they have different initial capital-to-labour ratios, there will be convergence as regards output and capital levels. The Solow model also predicts convergence in factor prices and the standard of living. In this case, convergence occurs not as a result of trade, but rather as a result of diminishing returns to investment in the more developed economies and economic sectors and variation in the rate of economic growth across countries. Where the ratio of capital to labour is high, additional capital inputs produce ever-smaller returns on investment. Economies that are less advanced and have lower capital-labour ratios are presumed to have higher rates of return and thus should converge to the income levels and standard of living of the more advanced economies. This growth-induced model of economic convergence differs from the trade liberalization model where trade no longer plays the central role.

In this model, depending upon assumptions about the mobility of capital and labour across borders, the convergence mechanism depends either on the movement of labour toward higher wages or the movement of capital toward higher returns on investment. 
The literature addressing the consequences of greater economic openness, trade liberalization, increased economic integration and closer association with the more advanced regions largely supports conventional assumptions about the positive benefits that countries should expect (Viner, 1950). Based primarily on the Heckscher-Ohlin (HO) model of international trade, predictions about these benefits are of two kinds. First, that economic integration improves economic competitiveness, promotes economic growth, reduces prices and increases aggregate welfare. Second, that integration promotes convergence in the costs of the factors of production (labour, capital and land), and ultimately in the standard of living. Both for the less and the more advanced economies, the benefits of economic integration are thought to be greater than the losses. With economic integration, economies should grow more rapidly; there should be an overall increase in the standard of living and less-skilled labour in the less-advanced countries should benefit from rising wages. The EU membership is seen as the logical conclusion of the process of economic integration. As such, if trade liberalization implies a greater capacity for economic competitiveness and growth, then the EU membership should generate the greatest possible return on the political decision to integrate. For example, Ben-David (1996) notes that convergence in the relative standard of living has occurred across groups of countries with strong trading relations. Convergence fails where countries are not integrated into the same trading networks. As predicted by the Factor Price Equalization theorem (FPE), the wages of low and unskilled workers are expected to increase in the less advanced countries and decline in the more advanced countries, but wages of highly skilled workers are expected to increase in the more advanced countries and decline in the less advanced countries.

It is worth to emphasize that the concept of conditional convergence, confirmed by the neoclassical theory, is rejected by many other models. Newer models of economic growth which belong to endogenous growth theory give completely different conclusions as regards the existence of convergence. The most important difference between the neoclassical and endogenous growth theory is that the latter does not assume decreasing returns to scale which were the main argument behind the catching-up process in the neoclassical models. All the endogenous models assume constant or increasing returns of factor inputs. This implies that these models do not confirm the existence of convergence (even in conditional terms).

For example, the Romer model of learning-by-doing (Romer, 1986) says that economic growth increases with income level, implying divergence processes. The same is confirmed by the Romer model with an expanding variety of products (Romer, 1990). The analysis of the transitional period in the two-sector Lucas model (Lucas, 1988) informs that the less developed countries may grow slower or faster than the more developed countries; it depends on whether poorer economies have scarce physical capital or human capital. The Aghion-Howitt model with an expanding quality of products (Aghion, Howitt, 1992) indicates that there is no relationship between income level and growth rate.

Although neoclassical models, which are the benchmark for our research, confirm only the conditional convergence hypothesis, we analyse unconditional convergence. We are allowed to do this because we may assume that the EU-10 countries have the same steady-state. They are many reasons for it. EU-10 countries are very homogenous 
economies. They do not differ much as regards population growth rates, savings rates and depreciation rates, i.e. the determinants of the steady-state according to the standard Solow model. Even considering the augmented Solow model, we may assume the same steady-states, because the human capital accumulation and technological accumulation, which are determinants of the steady-state according to the augmented Solow model and mentioned by other economists (e.g., Baumol, 1994), are very similar in our group of countries. The analysed countries have very similar political and institutional characteristics what is the next argument for the common steady-state according to, e.g., Sachs and Warner (1995). ${ }^{1}$

\section{Empirical Background}

Empirical research on economic growth has witnessed an enormous amount of interest during the last 20 years. Empirical analyses on convergence began to appear in the economic literature in the 1980s.

One of the first such studies was conducted by Baumol (1986) who argued that homogenous groups of countries grow according to the concept of convergence while heterogeneous groups of countries reveal rather divergence processes. His findings remain valid till now. Empirical analyses on convergence were popularized by Barro and Sala-i-Martin (e.g. Barro, 1989; Barro, Sala-i-Martin 2003) and Mankiw, Romer, Weil (Mankiw et al., 1992). In the empirical literature there are many analyses on income-level convergence, but most of them are based on two methods. The first one is the Barro-regression, where economic growth is regressed against the initial GDP level and other economic growth determinants. The second one is the Mankiw-Romer-Weil regression where economic growth is regressed against the initial income level and the variables which determine the steady-state of a given country according to the Solow model.

The empirical analyses on income-level convergence for CEE countries began to appear in the late 1990s. The most recent are: the European Commission, 2001; Wagner, Hlouskova, 2002; EEAG, 2004; Kaitila, 2004; Kutan, Yigit, 2005; Varblane, Vahter, 2005; Vojinovič, 2006; Matkowski, Próchniak 2007). Although these analyses vary between themselves as regards the period, the sample of countries, the data, and the method, their common result is that the new EU countries grew in line with the convergence hypothesis during the 1990s and 2000s. The convergence has appeared

1 The economic, political and institutional similarity is very well confirmed by Matkowski and Rapacki (2006). For example, for 8 CEE countries the share of the private sector in GDP in 2004 was from $65 \%$ (Slovenia) to $80 \%$ (the Czech Republic, Estonia, Hungary, and Slovakia); agriculture share in GDP in 2004 was from 3\% (Poland, the Czech Republic, Hungary, and Slovenia) to 6\% (Lithuania) whereas industry share was from 23\% (Latvia) to 38\% (the Czech Republic) and services share was from $59 \%$ (the Czech Republic) to $73 \%$ (Latvia) in the same year; foreign trade (as \% of GDP) was from $33.9 \%$ (Poland) to $69.4 \%$ (Slovakia) in 2004; average general government revenue (as \% of GDP) was from 30.3\% (Latvia) to 44.1\% (Hungary) in 1996-2004; average general government revenue (as \% of GDP) was from $34.0 \%$ (Latvia) to $49.2 \%$ (Hungary) in 1996-2004; average public investment (as \% of GDP) was from $1.4 \%$ (Latvia) to $4.2 \%$ (Estonia) in 1998-2003 (Matkowski, Rapacki, 2006). These indices as well as many others confirm the similarity between concerned economies. 
inside the New EU Member Countries as well as between these countries and former EU members. Nevertheless, the pace of catching-up process has been very slow. Thus we should not expect a rapid equalisation of income levels between the new and old EU countries.

Studies on real per-capita income convergence have discovered a two-percentper-annum rule of convergence (see, for example, Krugman, 1991 and Sala-i-Martin, 1996). Quah (1996) criticises this result, which claims that convergence takes place at a more or less uniform rate of $2 \%$ per year regardless of the geographic region under analysis. Indeed, there are many regions in the world that seem to be caught in a vicious cycle that is difficult to break away from. Among the EU countries we also find convergence at quite different speeds. Wagner and Hlouskova (2002) base their analysis on the historical convergence of the EU countries and then project it on the accession countries. They estimate the time it takes for the accession countries to catch up with the EU-15 countries. With the exception of the wealthier Slovenia and the Czech Republic, they estimate it to be three or four decades. Kaitila (2004) reports the rate of income convergence of $3.4 \%$ per-annum for 7 CEE countries (excluding Slovenia) and the period 1995-2001.

Varblane and Vahter (2005) confirms the existence of $\beta$ convergence in 10 transition countries during 1993-2004, but rejects the existence of $\sigma$ convergence among these countries during 1995-2005. Matkowski and Próchniak (2007) confirm the existence of $\beta$ and $\sigma$ convergence among the $8 \mathrm{CEE}$ countries as well as between these countries and EU-15. The speed of convergence is quite rapid as compared with a $2 \%$ rate. According to the newest research, 8 CEE countries have converged to the common steady-state at the rate of $5.1 \%$ in the years 1993-2005, meaning that CEE countries would need about 14 years to reduce by a half the distance to their common steady-state. The convergence to the European Union was significantly slower at the rate of ca $2.5 \%$.

\section{4. $\sigma$ convergence}

$\sigma$ convergence takes place when the dispersion of real per capita income declines over time. The dispersion of income levels can be measured by standard deviation, variation, or the coefficient of variation of GDP per capita levels between economies. All these indices yield similar results because the direction of change matters when analysing $\sigma$ convergence, not the absolute value of the indices. In our analysis we use coefficient of variation of GDP per capita at PPP (purchasing power parity) which is given by:

$$
C V=\frac{\text { standard deviation }}{\text { mean }}
$$

The results of $\sigma$ convergence analysis are presented in Table 1 and Figure 1. 
Table 1

GDP per Capita at Purchasing Power Parity (in USD), 1992-2006

\begin{tabular}{|l|r|r|r|r|r|r|r|r|r|r|r|r|r|r|r|}
\hline Country & $\mathbf{1 9 9 2}$ & $\mathbf{1 9 9 3}$ & $\mathbf{1 9 9 4}$ & $\mathbf{1 9 9 5}$ & $\mathbf{1 9 9 6}$ & $\mathbf{1 9 9 7}$ & $\mathbf{1 9 9 8}$ & $\mathbf{1 9 9 9}$ & $\mathbf{2 0 0 0}$ & $\mathbf{2 0 0 1}$ & $\mathbf{2 0 0 2}$ & $\mathbf{2 0 0 3}$ & $\mathbf{2 0 0 4}$ & $\mathbf{2 0 0 5}$ & $\mathbf{2 0 0 6}$ \\
\hline Cyprus & 11913 & 12047 & 12778 & 14016 & 14556 & 14912 & 15591 & 16334 & 17281 & 18172 & 18633 & 19135 & 20129 & 21232 & 22334 \\
\hline $\begin{array}{l}\text { Czech } \\
\text { Rep. }\end{array}$ & 10432 & 10680 & 11139 & 12053 & 12821 & 12943 & 12963 & 13223 & 13968 & 14750 & 15266 & 16074 & 17220 & 18375 & 19478 \\
\hline Estonia & 6157 & 5949 & 6279 & 6831 & 7384 & 8453 & 9010 & 9260 & 10258 & 11225 & 12300 & 13440 & 14926 & 16414 & 17802 \\
\hline Hungary & 8434 & 8605 & 9069 & 9431 & 9774 & 10432 & 11104 & 11779 & 12725 & 13601 & 14395 & 15196 & 16336 & 17405 & 18492 \\
\hline Latvia & 5002 & 4547 & 4820 & 5121 & 5484 & 6098 & 6522 & 6895 & 7600 & 8452 & 9226 & 10177 & 11396 & 12622 & 13784 \\
\hline Lithuania & 7341 & 6244 & 5770 & 6172 & 6790 & 7440 & 8129 & 8164 & 8730 & 9559 & 10420 & 11713 & 12856 & 14158 & 15443 \\
\hline Malta & 10947 & 11528 & 12214 & 13263 & 13948 & 14761 & 15354 & 16136 & 18017 & 18253 & 18667 & 18555 & 19100 & 19739 & 20365 \\
\hline Poland & 5739 & 6105 & 6547 & 7128 & 7693 & 8346 & 8839 & 9340 & 9914 & 10384 & 10719 & 11359 & 12293 & 12994 & 13797 \\
\hline $\begin{array}{l}\text { Slovak } \\
\text { Rep. }\end{array}$ & 7770 & 7629 & 8228 & 8870 & 9576 & 10165 & 10691 & 10985 & 11453 & 12161 & 12934 & 13775 & 14904 & 16041 & 17239 \\
\hline Slovenia & 10255 & 10844 & 11665 & 12392 & 13082 & 13973 & 14686 & 15658 & 16604 & 17423 & 18317 & 19161 & 20574 & 21911 & 23250 \\
\hline $\begin{array}{l}\text { St. } \\
\text { deviation }\end{array}$ & 2271 & 2562 & 2793 & 3047 & 3111 & 3045 & 3061 & 3267 & 3509 & 3449 & 3376 & 3151 & 3104 & 3099 & 3108 \\
\hline $\begin{array}{l}\text { Mean } \\
8399\end{array}$ & 8418 & 8851 & 9528 & 10111 & 10752 & 11289 & 11777 & 12655 & 13398 & 14088 & 14859 & 15973 & 17089 & 18198 \\
\hline $\begin{array}{l}\text { Coef. of } \\
\text { varia- } \\
\text { tion }(\sigma \\
\text { conver- } \\
\text { gence) }\end{array}$ & 0.27 & 0.30 & 0.32 & 0.32 & 0.31 & 0.28 & 0.27 & 0.28 & 0.28 & 0.26 & 0.24 & 0.21 & 0.19 & 0.18 & 0.17 \\
\hline
\end{tabular}

Source: International Monetary Fund, World Economic Outlook Database, September 2006; own calculations.

Table 1 shows GDP per capita at PPP levels in the EU-10 countries in the years 1992-2006, expressed in US dollars. The table also includes $\sigma$ convergence coefficients, calculated as coefficients of variation for the respective data. Figure 1 presents the dynamics of $\sigma$ convergence coefficients.

The data show high GDP per capita growth rates after 1994, clearly linked with sustainable growth of EU-10 economies. Faster growth of course presumes that poorer nations are capable of learning and adopting new and more efficient technologies and production processes. Also, there has to exist a well-functioning (or at least a working)

Figure 1

$\sigma$ Convergence of GDP per Capita at PPP in the EU-10 Countries, 1992-2006

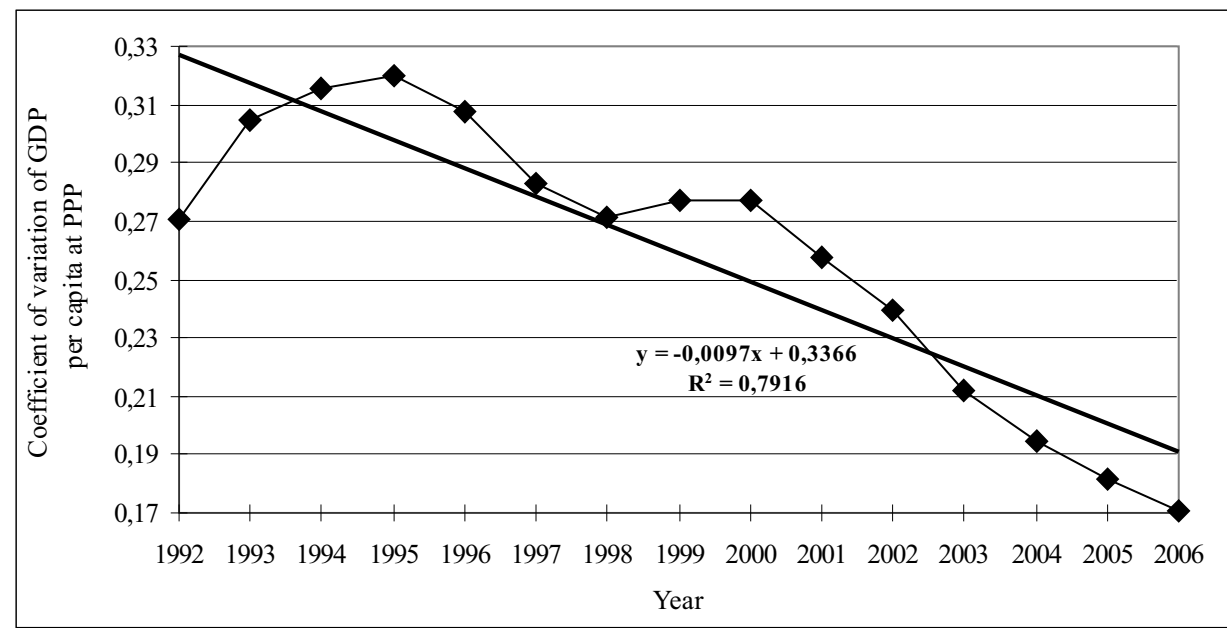

Source: Own calculations. 
legal, administrative and physical infrastructure and a stable enough macroeconomic and political environment.

The results clearly show that $\sigma$ convergence has occurred during the analysed period. It means that income differentiation among the New EU Member States has been decreasing during the transformation period (but the distance to EU-15 countries is still very big). The trend line for the period 1992-2006 has the negative slope -0.0097 with quite high $R$-square coefficient (0.7916).

However, the detailed analysis shows that in some years the EU-10 countries revealed $\sigma$-divergence. During 1992-1995 and 1998-1999 income differentiation between the concerned countries increased.

The $\sigma$-divergence in the first half of the 1990s was due to the transformation recession which in some countries (the Baltic states) lasted till the mid-1990s whereas in the other countries (e.g. Poland and Slovenia) the recession ended in the very beginnings of the 1990s.

For the CEE countries, membership in the European Union has likewise been seen as the key to political and economic stability, and ultimately prosperity. The return to Europe is expected to bring rewards surpassing the costs of EU accession and, in its pursuit, the governments of Central and Eastern Europe have adopted market reforms and EU regulations with a passion. Europe agreements and a gradual process of accession represented principal tool of economic renewal, trade liberalization protocols they contained and CEEC fulfilment of the broader objectives of market reform required for EU membership and laid out in a later White Paper from the European Commission ${ }^{2}$. For most countries in the sample, the transformation recession finished in 1993 or 1994 (except for Poland and Slovenia, where recession ended earlier, in 1991 and 1992, respectively). At the beginning of the 1990s, inflation rates soared up, with some countries experiencing hyper-inflations. By the end of the 1990s inflation had been brought down. Thus, among these countries, stabilization policy has been very fruitful, successful and growth is now widely experienced.

\section{5. $\beta$ convergence}

$\beta$ convergence occurs when the less developed countries grow faster than the more developed countries meaning that there is a negative relationship between initial income level and the growth rate. We analyse $\beta$ convergence among EU-10 economies using ordinary least squares regression based on panel data (yearly GDP growth rates $v s$ GDP levels from the preceding year) as well as cross-sectional data (average annual GDP growth rates $v s$ GDP levels from the beginning of the period).

In the case of the panel data, we estimate regression equations of the form:

$$
\log y_{i, t}-\log y_{i, t-1}=\alpha+\beta \log y_{i, t-1}+\varepsilon_{i, t},
$$

where $\log y_{i, t}$ is the natural logarithm of GDP per capita at PPP in country $i$ at time $t$, $\alpha$ is a constant and $\varepsilon$ is the error term.

2 See the European Commission's White Paper on the "Preparation of the Associated Countries of Central and Eastern Europe for Integration in the Internal Market of the European Union”

(European Commission, 1995). 
In the case of the cross-sectional data, we estimate regression equations of the form:

$$
\frac{1}{T} \log \frac{y_{i, T}}{y_{i, 0}}=\alpha_{0}+\alpha_{1} \log _{i, 0}+\varepsilon_{i},
$$

where $\log y_{T}$ and $\log y_{0}$ is the natural logarithm of GDP per capita at PPP in country $i$ in the last and the first year of the period, respectively, and $T$ indicates the length of the period. Convergence occurs when $\beta<0$ or $\alpha_{1}<0$, indicating that higher initial income level negatively affects the consequent growth rate. We analyse $\beta$ convergence for five different periods: 1992-1997, 1995-2006, 1996-2006, 2002-2006, and 2004-2006. Including various periods allows us to check the stability of the results. The results are presented in Figures 2-6 and in Tables 2-6.

Tables 2-6 present the results of regression equations based on panel data. The explained variable is the annual growth rate of GDP per capita at PPP whereas the explanatory variable is the GDP per capita at PPP level in the preceding year. For each period, except of the 1992-1997 period, GDP growth rate data are available for the year at which the period begins (thus, GDP levels for the first observation are taken from the year prior to the year at which the period begins). For the 1992-1997 period, the year 1992 is the first year for which GDP statistics are available (thus, GDP growth rates begins from 1993).

Figures 2-6 show the relationship between the average annual growth rate of GDP per capita at PPP and the initial GDP per capita at PPP level, for different periods. The figures are based on cross-sectional data. Thus, the regression equations displayed in the figures differ from the regression equations presented in the tables.

Figure 2

GDP per Capita Growth Rate during 1992-1997 vs the 1992 GDP per Capita Level

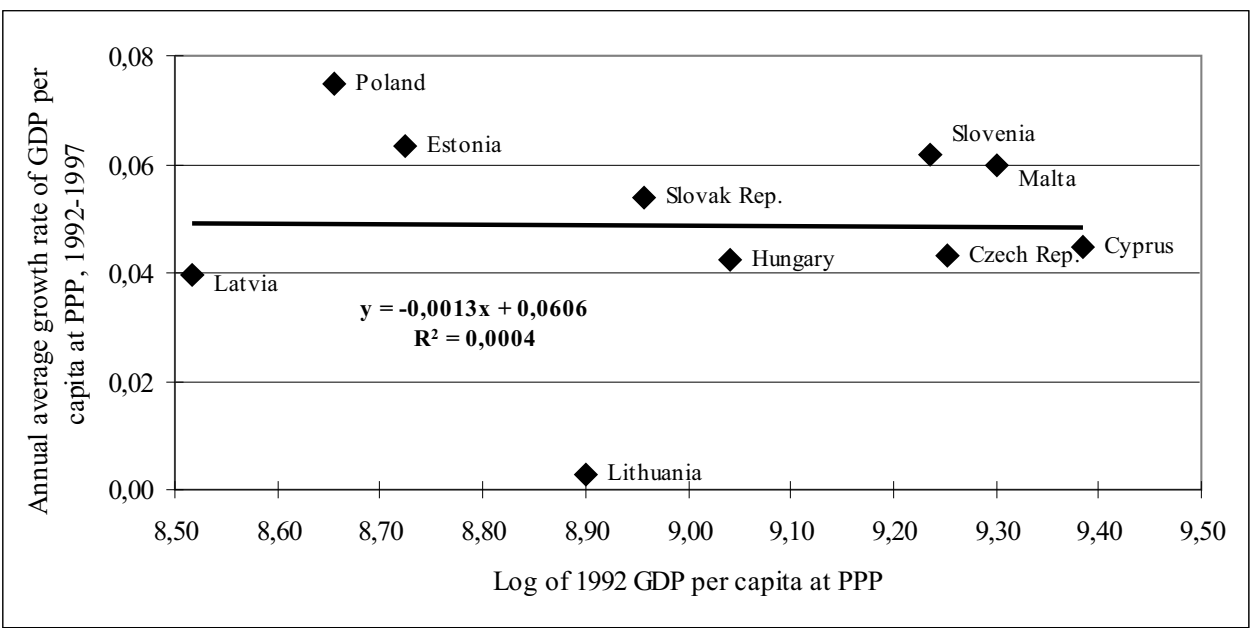

Source: Own calculations. 
Figure 3

GDP per Capita Growth Rate during 1995-2006 vs the 1995 GDP per Capita Level

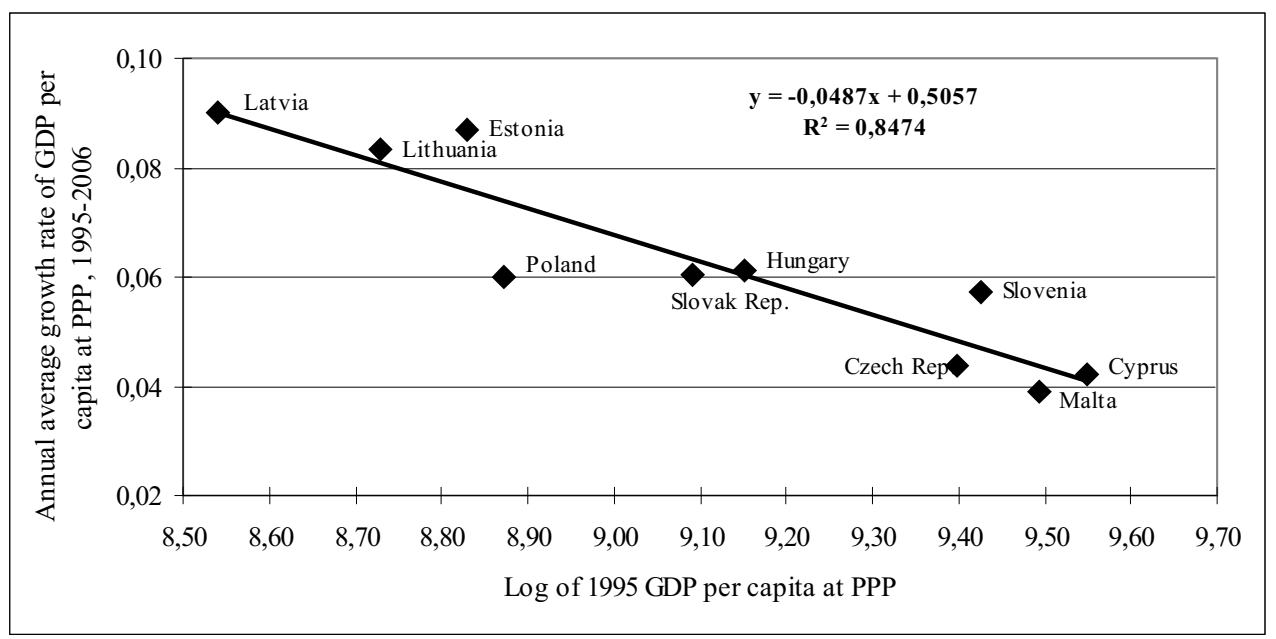

Source: Own calculations.

Figure 4

GDP per Capita Growth Rate during 1996-2006 vs the 1996 GDP per Capita Level

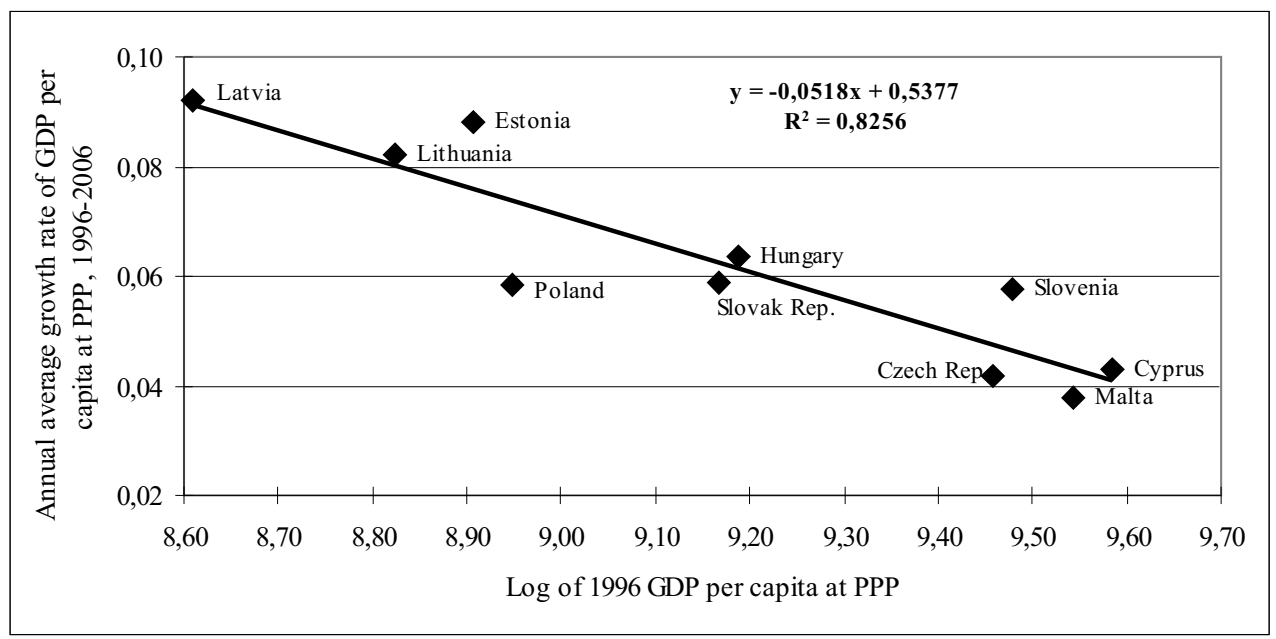

Source: Own calculations. 
Figure 5

GDP per Capita Growth Rate during 2002-2006 vs the 2002 GDP per Capita Level

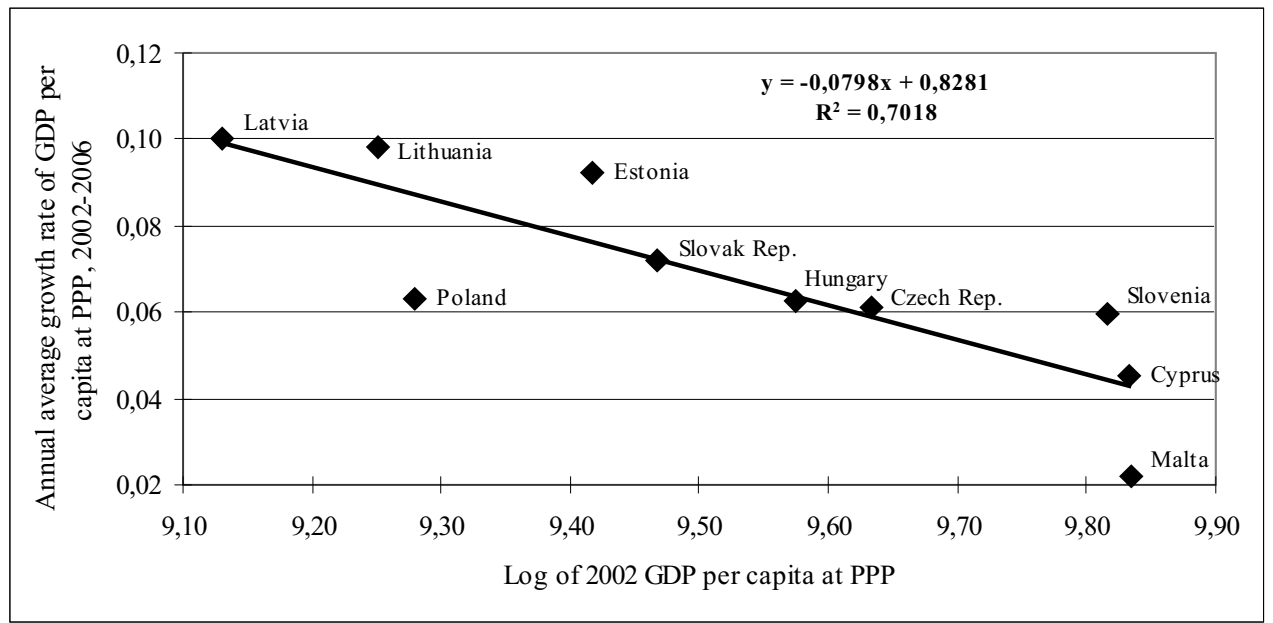

Source: Own calculations.

Figure 6

GDP per Capita Growth Rate during 2004-2006 vs. the 2004 GDP per Capita Level

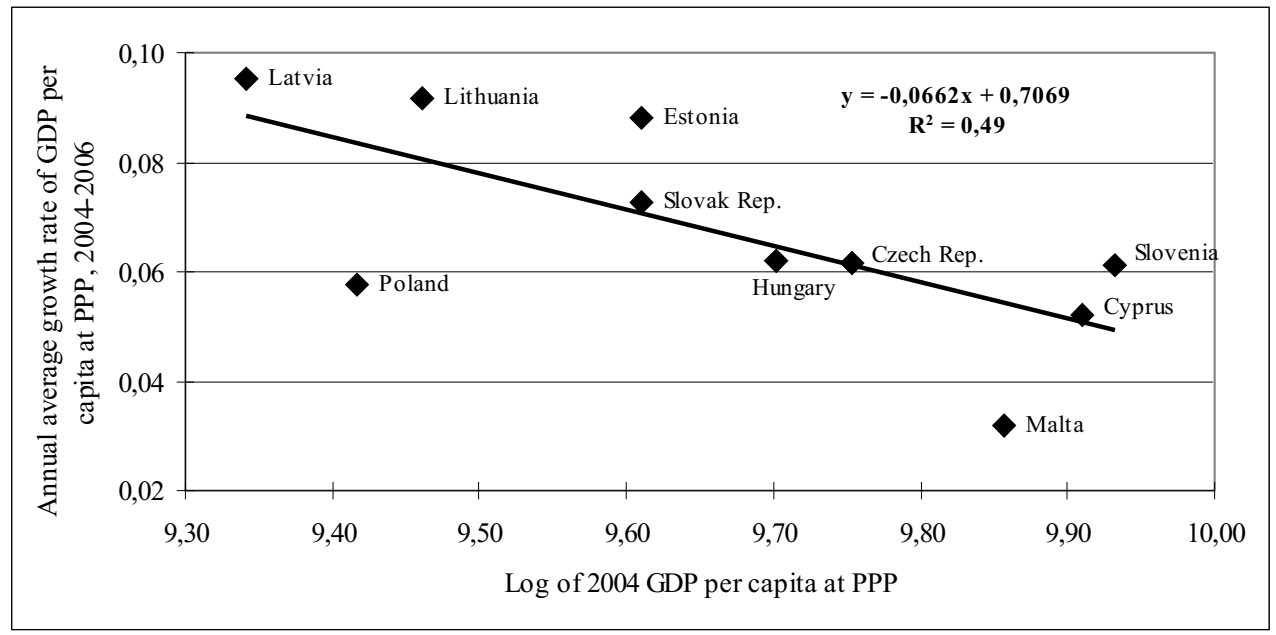

Source: Own calculations.

As we can see from the figures, there is a clear negative correlation between initial GDP per capita level and the growth rate for all the periods except of the 1992-1997 period. This confirms the unconditional $\beta$ convergence among the EU-10 countries in the second half of the 1990s and the 2000s. It implies the tendency of narrowing income differences among the countries concerned.

The Figures 3-6 contain the linear trends which fit very well to the points indicating the position of particular countries. This confirms an evident $\beta$-convergence during the second half of the 1990s and the 2000s. The linear trend for the period 1995-2006 is $y=-0.05 x+0.51$ 
with $R^{2}=0.85$. The trend line for the years 1996-2006 is $y=-0.05 x+0.54$ with $R^{2}=0.83$. For the period 2002-2006 and 2004-2006 the results are: $y=-0.08 x+0.83\left(R^{2}=0.70\right)$ and $y=-0.07 x+0.71\left(R^{2}=0.49\right)$. As we can see, these four regression lines have a negative slope with quite good statistical characteristics (high $R$-square coefficients).

The results for the period 1992-1997 reject the existence of $\beta$-convergence $(R$-square coefficient is actually zero). This is in line with the earlier results of testing $\sigma$-convergence where we observed that during 1992-1995 income differentiation between the countries increased.

The results based on panel data, displayed in Tables 2-6, yield the same conclusions as the results based on cross-sectional data. For each period, except of the 1992-1997 period, panel regressions confirm the existence of $\beta$-convergence. The $R$-square coefficients are at the acceptable level (from 0.15 for $1995-2006$ to 0.55 for 2004-2006). The explanatory variable is highly significant ( $p$-values are 0.000$)$. For the period 1992-1997 $R^{2}$ is zero and the explanatory variable is insignificant meaning that the convergence did not occur.

Based on the regression results, we can estimate the speed of convergence for various periods. We use the methodology applied by, e.g., Kaitila (2004), where the coefficient $\beta$ is simply the slope of the regression equation based on panel data. ${ }^{3}$ In the years 1995-2006 countries converged at the rate of $2.87 \%$, in $1996-2006-3.23 \%$, in $2002-2006-6.51 \%$, and in 2004-2006 - 7.46\%.

Table 2

Regression Results for $\beta$ Convergence in the EU-10 Countries, 1992-1997

\begin{tabular}{|c|c|c|c|c|}
\hline \multicolumn{5}{|c|}{ Dependent Variable: $\left(\log \mathrm{y}_{\mathrm{i}, \mathrm{t}}-\log \mathrm{y}_{\mathrm{i}, \mathrm{t}-1}\right)$} \\
\hline \multicolumn{5}{|c|}{ Method: OLS } \\
\hline \multicolumn{5}{|c|}{ Sample(adjusted): 1992-1997 } \\
\hline \multicolumn{5}{|c|}{ Included observations: 5} \\
\hline \multicolumn{5}{|c|}{ Number of cross-sections used: 10} \\
\hline \multicolumn{5}{|c|}{ Total panel (unbalanced) observations: 50} \\
\hline Variable & Coeffic. & Std. Error & t-Statistic & Prob. \\
\hline Constant & -.0512082 & .2020137 & -0.25 & 0.801 \\
\hline $\log y i, t-1$ & .0110232 & .0222833 & 0.49 & 0.623 \\
\hline R-squared & 0.0051 & Mean dependent var & & .0486595 \\
\hline Adjusted R-squared & -0.0157 & S.D. dependent var & & .0511154 \\
\hline S.E. of regression & .05151 & F-statistic & & 0.24 \\
\hline Sum squared resid & .12737709 & Prob(F-statistic) & & 0.6231 \\
\hline
\end{tabular}

Source: Own calculations.

3 However, many other authors (e.g., Matkowski and Próchniak, 2007) calculate the coefficient $\beta$ in a different form, from the following equation:

$$
\beta=-\frac{1}{T} \log (1+\lambda T)
$$

where $\lambda$ is the slope of the regresion and $T$ is the length of the period. 
Table 3

Regression Results for $\beta$ Convergence in the EU-10 Countries, 1995-2006

\begin{tabular}{|c|c|c|c|c|}
\hline \multicolumn{5}{|c|}{ Dependent Variable: $\left(\log \mathrm{y}_{\mathrm{i}, \mathrm{t}}-\log \mathrm{y}_{\mathrm{i}, \mathrm{t}-\mathrm{l}}\right)$} \\
\hline \multicolumn{5}{|l|}{ Method: OLS } \\
\hline \multicolumn{5}{|c|}{ Sample(adjusted): 1995-2006 } \\
\hline \multicolumn{5}{|c|}{ Included observations: 12} \\
\hline \multicolumn{5}{|c|}{ Number of cross-sections used: 10} \\
\hline \multicolumn{5}{|c|}{ Total panel (unbalanced) observations: 120} \\
\hline Variable & Coeffic. & Std. Error & $\mathrm{t}$-Statistic & Prob. \\
\hline Constant & .3328107 & .0589358 & 5.65 & 0.000 \\
\hline $\log \mathrm{yi}, \mathrm{t}-1$ & -.0287372 & .0062793 & -4.58 & 0.000 \\
\hline R-squared & 0.1507 & Mean dependent var. & & .063276 \\
\hline Adjusted R-square & 0.1435 & S.D. dependent var. & & .0257674 \\
\hline S.E. of regression & .02385 & F-statistic & & 20.94 \\
\hline Sum squared resid. & .06710118 & $\operatorname{Prob}(\mathrm{F}$-statistic) & & 0.0000 \\
\hline
\end{tabular}

Source: Own calculations.

Table 4

Regression Results for $\beta$ Convergence in the EU-10 Countries, 1996-2006

\begin{tabular}{|c|c|c|c|c|}
\hline \multicolumn{5}{|c|}{ Dependent Variable: $\left(\log \mathrm{y}_{\mathrm{i}, \mathrm{t}}-\log \mathrm{y}_{\mathrm{i}, \mathrm{t}-\mathrm{l}}\right)$} \\
\hline \multicolumn{5}{|l|}{ Method: OLS } \\
\hline \multicolumn{5}{|c|}{ Sample(adjusted): 1996-2006 } \\
\hline \multicolumn{5}{|c|}{ Included observations: 11} \\
\hline \multicolumn{5}{|c|}{ Number of cross-sections used: 10} \\
\hline \multicolumn{5}{|c|}{ Total panel (unbalanced) observations: 110} \\
\hline Variable & Coeffic. & Std. Error & t-Statistic & Prob. \\
\hline Constant & .3667283 & .0657132 & 5.58 & 0.000 \\
\hline $\log y_{i, t-1}$ & -.0323357 & .0069786 & -4.63 & 0.000 \\
\hline R-squared & 0.1658 & Mean dependent var. & & .0624298 \\
\hline Adjusted R-squared & 0.1581 & S.D. dependent var. & & .0263707 \\
\hline S.E. of regression & .0242 & F-statistic & & 21.47 \\
\hline Sum squared resid. & .063230308 & Prob(F-statistic) & & 0.0000 \\
\hline
\end{tabular}

Source: Own calculations. 
Table 5

Regression Results for $\beta$ Convergence in the EU-10 Countries, 2002-2006

\begin{tabular}{|c|c|c|c|c|}
\hline $\begin{array}{l}\text { Dependent Variable } \\
\text { Method: OLS } \\
\text { Sample(adjusted): } 2 \\
\text { Included observatior } \\
\text { Number of cross-sec } \\
\text { Total panel (unbalan }\end{array}$ & $\begin{array}{l}10 \\
\text { ations: } 50\end{array}$ & & & \\
\hline Variable & Coeffic. & Std. Error & t-Statistic & Prob. \\
\hline Constant & .6893353 & .1169944 & 5.89 & 0.000 \\
\hline $\log \mathrm{yi}, \mathrm{t}-1$ & -.0650775 & .012192 & -5.34 & 0.000 \\
\hline R-squared & 0.3725 & Mean dependent var. & & .0650508 \\
\hline Adjusted R-squared & 0.3594 & S.D. dependent var. & & .0260024 \\
\hline S.E. of regression & .02081 & F-statistic & & 28.49 \\
\hline Sum squared resid. & .020789869 & Prob(F-statistic) & & 0.0000 \\
\hline
\end{tabular}

Source: Own calculations.

Table 6

Regression Results for $\beta$ Convergence in the EU-10 Countries, 2004-2006

\begin{tabular}{|c|c|c|c|c|}
\hline \multicolumn{5}{|c|}{ Dependent Variable: $\left(\log \mathrm{y}_{\mathrm{i}, \mathrm{t}}-\log \mathrm{y}_{\mathrm{i}, \mathrm{t}-1}\right)$} \\
\hline \multicolumn{5}{|l|}{ Method: OLS } \\
\hline \multicolumn{5}{|c|}{ Sample(adjusted): 2004-2006 } \\
\hline \multicolumn{5}{|c|}{ Included observations: 3} \\
\hline \multicolumn{5}{|c|}{ Number of cross-sections used: 10} \\
\hline \multicolumn{5}{|c|}{ Total panel (unbalanced) observations: 30} \\
\hline Variable & Coeffic. & Std. Error & t-Statistic & Prob. \\
\hline Constant & .7905301 & .1236447 & 6.39 & 0.000 \\
\hline $\log y_{i, t-1}$ & -.0745781 & .0128002 & -5.83 & 0.000 \\
\hline R-squared & 0.5480 & Mean dependent var. & & .0703031 \\
\hline Adjusted R-squared & 0.5319 & S.D. dependent var. & & .021373 \\
\hline S.E. of regression & .01462 & F-statistic & & 33.95 \\
\hline Sum squared resid. & .005987851 & Prob(F-statistic) & & 0.0000 \\
\hline
\end{tabular}

Source: Own calculations.

As we can see, the convergence among New EU Member Countries is quite rapid as compared with a $2 \%$ rate of convergence, most frequently cited in the literature and observed for very wide groups of countries. However, our estimates of the coefficient $\beta$ are very similar to the estimates obtained by Matkowski and Próchniak who analysed $8 \mathrm{CEE}$ countries in various periods. This reinforces our conclusions.

There are many reasons why we have obtained such results. First, according to the neoclassical growth theory, marginal products of factor inputs are decreasing what implies that capital flows from more developed economies to less developed ones where rates of return are higher.

This capital inflow, which often takes the form of foreign direct investments, yields the increase in potential as well as real output in the destination country. Second, the CEE 
countries pursued the same economic policy during the transition period. They transformed their economies from centrally planned to market oriented ones implementing very similar structural, institutional, and political reforms. The countries which introduced the reforms early in the 1990s could rapidly become relatively rich and then could reveal moderate growth rates. The countries which reformed their economies later could remain poor even till the mid-1990s but - if so - they should have revealed high growth rates in the late 1990s and 2000s. The third argument behind the convergence was linked with the size of transformation crisis and the consequent come-back to pre-transformation income level. The countries which recorded a deep recession at the beginning of 1990s - in order to return to the 1989 income level - should growth faster than the countries which noticed a less severe transformation recession. Last but not least, all the analysed countries were expected to join the EU. The EU pursued the policy aimed at reducing the differences in the development levels. The EU Structural Funds were allocated to poorer regions and countries allowing them to grow at a higher rate.

Our results also confirm the fact that New EU Member States converged at a higher rate than the process of convergence took place in the group of old EU members. This finding is in line with neoclassical growth theory that supports the occurrence of convergence among similar countries and with Hecksher-Ohlin theory of international trade. The latter means that, in principle, poorer countries have some advantage over wealthier ones in economic growth (i.e., poorer regions and countries tend to grow faster than richer ones and could eventually catch up with them).

Labour-abundant countries will specialise in the production and exports of labour-intensive goods and capital-abundant countries will specialise in the production and exports of capital-intensive goods. This would lead to incumbent EU countries specialising more in capital-intensive production and the accession countries in labour-intensive production. The former are generally thought to have an advantage in capital and skill-intensive manufacturing, business and financial services while the accession countries are thought to have an advantage in labour-intensive sectors, tourism and transportation. Although labour costs in the accession countries are significantly lower than in the incumbent EU countries, the former are not particularly abundant in labour in the way we may say the less developed countries are. Furthermore, the accession countries also have a fairly educated and trained labour force.

These features, along with FDI inflows from the EU countries, produce a situation where these countries also compete in certain knowledge and capital-intensive sectors. Still, there is room for specialisation in the lines of the incumbent EU countries' and accession countries' competitive advantage.

The liberalisation of trade should increase growth through cheaper inputs, an increase in competition that leads to higher productivity and lower prices, and larger markets in the foreign countries. Free trade may also lead to an increase in FDI flows and thereby to technological diffusion. 


\section{Conclusion}

This paper estimates and analyses $\sigma$ and unconditional $\beta$ per capita income convergence among the ten European countries that accessed the European Union in 2004. Our results confirm the existence of both types of convergence. The poorer New EU Member States grew generally faster in the transition period than richer new EU Member States. As a result, the income gap between these countries has decreased, although it still remains quite large. Our analysis reveals that the convergence took place in the second half of the 1990s and the 2000s whereas in the first half of the 1990s, the countries rather diverged or at least did not converge. Subdividing the overall period of 1995-2006 into 1995-2006, 1996-2006, 2002-2006, and 2004-2006, while estimating $\beta$ convergence among EU10 countries, we observe the rate of convergence becoming faster over the successive period. This implies that effective integration of the New Member States is going on. Furthermore, it will help the integration of EU15 and EU10 countries as well. The convergence occurred at the rate of $2.87 \%$ during $1995-2006$ and $3.23 \%$ during 1996-2006. Though some of the previous studies also concluded the speed of convergence very closer to what this study estimated, this study is also able to explore some divergences of per capita income among the EU10 countries during 1992-97.

Our estimation of $\sigma$ and unconditional $\beta$ convergences of per capita GDP among the EU10 countries lead us to a robust conclusion that Central and Eastern European countries diverged to some extent during 1992-97, but converged afterwards. The reasons of short-term divergence in per capita GDP were recessions during early nineties in some transition economies, lack of well developed market systems among them, and lack of EU policy in reducing income disparity at the beginning of the 1990s. However, after the economic recovery, promotion of the market systems and effective EU policy in reducing disparities among the EU countries not only helped substantially in reducing the per capita GDP divergence, it also helped its convergence among the New Member States. Continual decline in the $\sigma$ convergence among the EU10 countries after 1997 has two implications. In the first place, there is the tendency of long-term convergence of per capita GDP so long as the current EU policies prolong. In the second place, low-income EU10 countries reveal the further prospect of capital inflow from developed EU countries.

\section{References}

Aghion, P., Howitt, P. (1992), "A Model of Growth through Creative Destruction”. Econometrica, 60, pp. 323-351.

Barro, R. J. (1989), "Economic Growth in a Cross Section of Countries”. NBER Working Papers, No. 3120.

Barro, R. J., Sala-I-Martin, X. (1990), "Economic Growth and Convergence across the United States". Cambridge, NBER Working Paper No. 3419.

Barro, R. J., Sala-I-Martin, X. (2003), Economic Growth. Cambridge; London : The MIT Press.

Baumol, W. J. (1986), "Productivity Growth, Convergence, and Welfare: What the Long-Run Data Show". American Economic Review, (76), pp. 1072-1085.

Baumol, W. J. (1994), "Multivariate Growth Patterns: Contagion and Common Forces as Possible Sources of Convergence", in Baumol, W., Nelson, R. R., Wolf, E. J., eds., Convergence of Productivity. New York : Oxford University Press, pp. 62-85.

Ben-David, D. (1996), "Trade and Convergence Among Countries". Journal of International Economics, 40, pp. 279-98. 
Cass, D. (1965), "Optimum Growth in an Aggregative Model of Capital Accumulation". Review of Economic Studies, 32, pp. 233-240.

Demelo, M., Denizer, C., Gelb, A., Tenev, S. (1997), "Circumstance and Choice: The Role of Initial Conditions and Policies in Transition Economies". Washington : International Finance Corporation.

Diamond, P. A. (1965), "National Debt in a Neoclassical Growth Model". American Economic Review, 55, pp. 1126-1150.

EEAG (2004), "Report on the European Economy 2004". Munich : CESifo.

European Commission (2001), "The Economic Impact of Enlargement". Enlargement Paper No. 4.

European Commission (1995), "White Paper: Preparation of the Associated Countries of Central and Eastern Europe for Integration into the Internal Market of the Union". EUR-OP (COM(95)163), Luxembourg.

Fischer, S., Sahay, R. (2000), “The Transition Economies after 10 years”. IMF Working Paper, No. 00/30.

Havrylyshyn, I., Ivorski, I., Van Rooden, R. (1998), "Recovery and Growth in Transition Economies 1990-97: A Stylized Regression Analysis". IMF Working Paper, No. 98/141.

Kaitila, V. (2004), "Convergence of Real GDP per Capita in the EU15. How Do the Accession Countries Fit In?" European Network of Economic Policy Research Institutes Working Paper, No. 25.

Koopmans, T. (1965), On the Concept of Optimal Economic Growth: The Econometric Approach to Development Planning. Amsterdam : North Holland.

Kutan, A. M., Yigit, T. M. (2005), "Real and Nominal Stochastic Convergence: Are the New EU Members Ready to Join the Eurozone?" Journal of Comparative Economics, 33, pp. 387-400.

Krugman, P. (1991), Geography and Trade. Cambridge, MA : MIT Press.

Lucas, R. E. (1988), "On the Mechanics of Economic Development". Journal of Monetary Economics, 22, pp. 3-42.

Mankiw, N. G., Romer, D., Weil, D. N. (1992), "A Contribution to the Empirics of Economic Growth”. The Quarterly Journal of Economics, May.

Matkowski, Z., Próchniak, M. (2007), "Economic Convergence Between the CEE-8 and the European Union". Eastern European Economics, 45 (1), pp. 59-76.

Matkowski, Z., Rapacki, R. (2006), "The Economic Situation and the Progress of Market Reforms", in Rosati D., ed., New Europe. Report on Transformation XVI Economic Forum. Warsaw, Poland, Krynica, 6-9 September 2006, Foundation Institute for Eastern Studies, 2006, pp. 99-212.

Quah, D. T. (1996), "Empirics for Economic Growth and Convergence". European Economic Revue, 40, pp. 1353-75.

Ramsey, F. P. (1928), "A Mathematical Theory of Saving". Economic Journal, 38, pp. 543-559.

Rey, S. J., Montouri, B. D. (1998), "US Regional Income Convergence: A Spatial Econometric Perspective". Regional Studies, 33, pp. 145-156.

Romer, P. M. (1986), "Increasing Returns and Long-Run Growth”. Journal of Political Economy, 94, pp. 1002-1037.

Romer, P. M. (1990), "Endogenous Technological Change". Journal of Political Economy, 98, pp. S71-S102.

Sachs D. J., Warner, A. M. (1995), "Economic Convergence and Economic Policies”. NBER Working Paper, No. 5039.

Sala-I-Martin, X. (1996), "Regional Cohesion: Evidence and Theories of Regional Growth and Convergence". European Economic Review, 40, pp. 1325-52.

Solow, R. (1956), "A Contribution to the Theory of Economic Growth". Quarterly Journal of Economics, 70, pp. 65-94.

Swan, T. (1956), "Economic Growth and Capital Accumulation”. Economic Record, 32, pp. 334-361.

Varblane U., Vahter P. (2005), "An Analysis of the Economic Convergence Process in the Transition Countries". University of Tartu (unpublished).

Viner, J. (1950), The Custom Union Issue. New York : Canergie Endowment for International Peace.

Vojinovič, B. (2006), "Convergence, Growth, Welfare and European Integration: Rate of Income Convergence in the New Members of the European Union; Empirical Assessment". Presented at the $9^{\text {th }}$ EACES Conference, Brighton (UK), 7-9 September 2006.

Wagner, M., Hlouskova, J. (2002), “The CEEC10's Real Convergence Prospects”. Washington, CEPR Discussion Paper, No. 3318. 